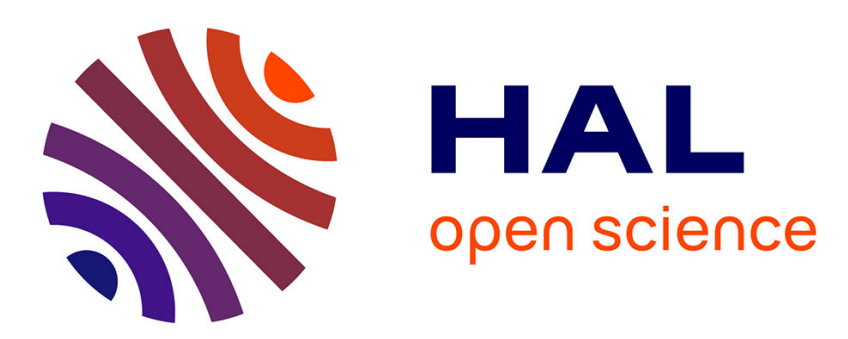

\title{
The role of social identity in the explanation of collective action: An intergroup perspective on the Yellow Vests movement
}

Jaïs Adam-Troian, Yara Mahfud, Karolina Urbanska, Serge Guimond

\section{To cite this version:}

Jaïs Adam-Troian, Yara Mahfud, Karolina Urbanska, Serge Guimond. The role of social identity in the explanation of collective action: An intergroup perspective on the Yellow Vests movement. Journal of Applied Social Psychology, 2021, 51 (6), pp.560-576. 10.1111/jasp.12757 . hal-03421135

\section{HAL Id: hal-03421135 \\ https://hal.science/hal-03421135}

Submitted on 30 Nov 2021

HAL is a multi-disciplinary open access archive for the deposit and dissemination of scientific research documents, whether they are published or not. The documents may come from teaching and research institutions in France or abroad, or from public or private research centers.
L'archive ouverte pluridisciplinaire HAL, est destinée au dépôt et à la diffusion de documents scientifiques de niveau recherche, publiés ou non, émanant des établissements d'enseignement et de recherche français ou étrangers, des laboratoires publics ou privés. 


\title{
The role of social identity in the explanation of collective action: An intergroup perspective on the Yellow Vests Movement
}

\author{
Jaïs Adam-Troian \\ Aix-Marseille University, France \\ American University of Sharjah, UAE \\ Yara Mahfud \\ University of Paris X, France \\ Karolina Urbanska \\ Department of Psychology, University of Sheffield, United Kingdom
}

\section{Serge Guimond}

Laboratoire de Psychologie Sociale et Cognitive, Université Clermont Auvergne, France 


\title{
The role of social identity in the explanation of collective action: An intergroup perspective on the Yellow Vests Movement
}

\begin{abstract}
Social psychologists have developed influential theoretical models to understand intergroup conflicts, radicalism and collective action. November 2018 saw the emergence of a new powerful movement in France named the Yellow Vests. Born on social media, the movement has sustained an unprecedented period of intense protests and violent clashes with the police, challenging the French government. As such, this movement offers an ideal context to examine the real-world relevance of current social-psychological theorizing. Using a social identity and self-categorization perspective (Turner \& Reynolds, 2012), two correlational studies (three samples, $\mathrm{N}=1849$ ) tested the role of self-categorization as a group member, or social identity, in accounting for individual participation in normative and non-normative collective action. Using different operationalizations of identification, both studies confirm a powerful role of identification as a Yellow Vest and provided evidence that the effect of social media use on collective action is fully mediated by self-categorization as a Yellow Vest. An alternative model suggesting that social media use mediated the relation between social identity and collective action was not supported by the data.
\end{abstract}

Keywords: social identity, collective action, social media, yellow vests, political ideology 


\section{Introduction}

Born on social media platforms in 2018, the Yellow Vest movement in France has shaken the social and political fabric of the French establishment in unprecedented ways (see Noiriel, 2019). Its impact has been compared to the movements of greatest historical significance in France and worldwide, including the French Revolution (Mazeau, 2019). What are the main factors that led individuals to take part in this movement? The central purpose of the present research is to address this question empirically. The events surrounding this movement, spanning over more than 14 months, occurring all over France and spreading to the neighboring countries, form an extremely complex picture of human social and political behaviors. The historical, economic, and political intricacies of this movement are far beyond the scope of this article. Nevertheless, we will go beyond mere speculations to document some of the most significant social-psychological factors that have often been overlooked in analyses of the movement conducted so far. Theoretically grounded in the social identity and self-categorization perspective (Turner \& Reynolds, 2001; 2012), Study 1 tested the hypothesis that self-categorization as a Yellow Vest, and not political ideology, motivated normative and non-normative collective behaviors, among the general population (Study 1a) and students (Study 1b). In Study 2, we replicate the findings of Study 1a and $1 \mathrm{~b}$ by using a different set of measures and we further examine connections between social media use, social identity and collective action. The findings suggest that the Yellow Vest movement succeeded in mobilizing people across France because it created, through social media, a highly distinctive and novel social identity that accommodated people of extremely diverse political orientations from left to right.

\subsection{How do people come to think, feel, and act as a psychological group?}

The social identity perspective in social psychology comprises social identity theory (SIT; Tajfel \& Turner, 1979) and self-categorization theory (SCT; Turner, et al., 1987). From 
this perspective, the categorization of self as a group member is the main factor that accounts for collective behavior (Turner et al., 1987). This is a social-psychological hypothesis for two main reasons. First, it emphasizes the importance of subjective group membership, not objectively defined membership in a social category or social class (see McGarty et al., 2009). Second, it asserts that relationships with others and group belonging can produce important and sometimes radical changes in human psychology in a manner that individual psychology cannot account for (Turner, et al., 1994). Previous research sometimes found only weak relations between group identification and the intention to take protest action (see Kelly \& Breinlinger, 1995; de Weerd \& Klandermans, 1999). However, recent reviews of the evidence confirm an important role of social identity in collective action (Craig et al., 2020; Thomas et al., 2020; van Zomeren et al., 2008). Thus, with regards to the Yellow Vest movement, or any other social movements, one does not need to infer some unusual individual psychological traits to account for participation in the movement: coming to perceive oneself as a group member can be sufficient to trigger action. This suggests that besides the economic, political and historical factors that are undoubtedly involved in such intergroup struggles, the ability of the Yellow Vest movement to mobilize thousands of French citizens could be a product of the way that the movement has created a new and highly distinctive identity.

\subsection{Previous research on the Yellow Vest}

The Yellow Vest movement has generated tremendous interest in the news media and also among scholars and survey institutes (Algan, et al., 2019; IFOP, 2018; Lelan, et al., 2018; Noiriel, 2019). Amidst numerous analyses focusing mainly on the socio-structural and ideological background of those involved in the movement, a key insight emerged from Jetten et al. (2020) who pointed out that identity processes are at the core of the Yellow Vest movement. According to them, the Yellow Vest identity emerged as a strong reaction to the perceived violations of the core French value of equality by the government. Thus, in this 
conceptual analysis, Jetten et al. (2020) assume a role for national French identity. It is true that the Yellow Vests frequently demonstrated their attachment to France by using various national symbols in their actions. Nevertheless, the focus of our research is on the Yellow Vest identity itself because it corresponds to a politicized identity (Simon \& Klandermans, 2001). Previous research has shown that politicized identities, compared to non-politicized identities, are a stronger predictor of collective action (van Zomeren et al., 2008).

Overall, the results of past analyses of the movement are consistent and three main findings can be extrapolated. First, in contrast to the movements in the 1970's where men were dominant participants, the Yellow Vest is a movement in which women have taken a place as important as men. Second, the people involved in the Yellow Vest movement tended to be of working class backgrounds, living outside large urban centers; they are more likely to worry about how they are going to pay their bills compared to others. In other words, social class can account for the mobilization to some extent. Finally, in terms of political affiliation, the Yellow Vest comprises three political voter groups: those voting for 'France Insoumise' (and aligning with the extreme left ideologies), those voting for 'Rassemblement National' (and aligning with the extreme right) and non-voters. In other words, this was not a movement of the left against the right-wing establishment. A movement ingrained in a specific political orientation would struggle to accommodate such diverse political perspectives.

Instead, an identity built on an anti-government opposition makes a more useful mobilizing tool than political affiliation. For these reasons, the present research provides a formal test of whether identification as a Yellow Vest is indeed a more powerful driver of collective mobilization than political orientation (i.e., on a spectrum from extreme left-wing to extreme right-wing), or other demographic variables

Furthermore, testing the role of social identity in the context of the Yellow Vest movement may be extremely useful to help clarify two fundamental issues that have assumed 
increasing importance in recent years. First, can social identity explain both normative and non-normative collective action? And second, is the social identity analysis useful even when considering the effects of new communication technologies that are assumed to shape political participation in new directions?

\subsection{Normative and non-normative collective action}

Wright et al. (1990) have proposed a distinction between normative collective action, action that conforms to the norms of the existing social system such as political participation or peaceful protest, and non-normative collective action, that is action that violates these rules, such as violence and terrorism. Reviewing and integrating existing research, the Social Identity Model of Collective Action (van Zomeren et al., 2008) has shown that there is empirical support for three main predictors of collective action: perceived injustice and concomitant intergroup emotions (e.g., anger), group efficacy and social identity. However, this model did not clearly distinguish between normative and non-normative collective actions. Indeed, Tausch et al. (2011) showed that two of these determinants, group efficacy and intergroup emotions, do not predict normative and non-normative collective action in similar ways. Tausch et al. (2011), however, did not examine the role of social identity in these initial studies. While Becker and Tausch (2015) subsequently suggested that contrary to group-based emotions and group efficacy, social identity may be equally important for both normative and non-normative collective action, preliminary evidence suggests that social identity is a stronger predictor of normative collective action than non-normative (Stathi et al., 2019). Related work also shows that identification with Yellow Vest can be related to nonnormative collective action, but this research considered only general behaviors and not those pertinent to Yellow Vests (Adam-Troian, et al. 2020). Nevertheless, little research has been conducted on this question and there are divergent theoretical positions with regards to the role of social identity in the explanation of more radical forms of actions. 
While many scholars tend to focus on individual biological or cognitive factors as the root cause of extremism, paying less attention to group and intergroup processes at stake (see van Prooijen \& Krouwel, 2019; Zmigrod and Goldenberg, 2020), others consider social identity one as of the most important factors. For example, Ginges et al. (2011) argue that 'to understand political violence we need to know more about the way moral commitment to the in-group, and values closely associated with group identity, can trump individual level motivations' (p. 17). This suggests, in line with the social identity perspective, that a focus on individual level motivations may paint an uncomplete picture of drivers of non-normative means to protest.

More importantly, findings from the Elaborated Social Identity Model of Crowd Behavior (Stott et al., 2018) show how protesters' interactions with law enforcement shape their perception of protest violence as a legitimate strategy. When people participate in collective action and face police brutality, this can increase their identification with the group and intensify their commitment to take action (Drury \& Reicher, 2000; Reicher, 1996). This should be especially true of movements such as the Yellow Vest, which have been characterized by a high prevalence of police and protester violence (Jetten et al., 2020). This is converging with research on hooliganism which shows that the likelihood of protesters committing illegal and violent actions is higher when police use force in a disproportionate way (e.g. 'preventively'; Stott and Pearson 2007).

Similarly, having considered from an historical perspective a broad range of movements involving political violence, Sageman (2017) argued, paraphrasing Turner et al. (1987), that: 'Self-categorization, or the acquisition of a shared social identity, is what makes collective behavior possible' (p.6). He suggests that self-categorization is the single most important theory to understand political violence. Based on this analysis and the existing empirical research (e.g. Smith et al., 2019; Reicher et al., 2004), it is expected that social 
identity may be involved in motivating non-normative collective action as well as normative collective action. The Yellow Vest movement offers a uniquely relevant context to test this hypothesis directly because while much of the actions taken within this movement were normative, spectacular cases of non-normative actions were also noted. Furthermore, the fact that the Yellow Vest often refer to the French Revolution (Jetten et al., 2020) should hint us that revolutionary (i.e. nonnormative) action may constitute a central component of the

\section{Yellow Vest identity.}

This is an area were systematic empirical research is important and needed. As McPhail and Schweingruber (1998) highlighted, most citizens and scholars alike learn about current episodes of political violence through the mass media. The media are selective in their coverage in that they often focus on negative events while ignoring the more prevalent, nonviolent events. Relying on one's impressions derived from the exposure to media coverage does not represent a reasonable basis to analyze the Yellow Vest movement. For this reason, the present research sought to measure in a systematic manner the involvement in the Yellow Vest movement based on several random samples of the French populations who indicated their level of intended or actual participation. This participation concerns behaviors that are located at the intergroup pole of the interpersonal-intergroup continuum of social behavior and as such, the social identity perspective predicts that identification as a group member should be a major explanatory factor.

\subsection{Social media and Collective Action}

A second question of increasing importance concerns the role of social media platforms defined as websites allowing individuals to construct a profile and to articulate a list of users with whom they share a connection (see Huang, 2017). McPhail and Miller (1973) have developed an original and underappreciated analysis of collective gathering that resonate with the widespread impact of social media platforms. They tried to understand how 
individuals navigate from disparate points in space at one timepoint to a common location at another timepoint. Instead of looking at people's beliefs and attitudes, they argued for the need to consider communication processes and ecological factors. Their study concluded that verbal and non-verbal instructions which establish the time-space location of an event are strongly related to the actual participation in the collective gathering. In other words, how people communicate with one another to organize a movement is key to participation in that movement. Although scarce, subsequent research provided additional support for this perspective (see Guimond, 2003, 2010).

Since McPhail and Miller (1973) conducted their study, however, the way people communicate with one another has changed considerably, especially with the technological advances and growing access to social media. When troubled by an event, people use Internet and search engines to learn more (Troian et al., 2019). Moreover, through social media platforms, they can engage in exchange of information and points of view about social and political events. In line with this, there is overall empirical support for the idea that the use of social media is related to increased political participation (Boulianne, 2015). In short, the communication can now occur with little effort across extremely large populations. As such, the use of social media platforms is now considered to be a important factor in understanding collective action (Alberici \& Milesi, 2015; Bimber, 2017).

The importance of social media in collective action has been documented in the case of the Arab Spring, a wave of anti-government protest that started in Tunisia in December 2010 and spread rapidly due to social media to Egypt, Libya and Yemen (Blakemore, 2019). In these countries, segments of the population shared information and coordinated their action through social media (Marzouki \& Oullier, 2014) and succeeded in bringing about radical political changes. Similarly, the Yellow Vest movement is essentially the product of social media platforms, formed by ordinary people without any political or non-political leadership. 
It started with an online petition against a tax increase targeting diesel-powered vehicles, receiving 226,000 signatures in 10 days, and escalating to 860,000 signatures on the eve of a general call to make the 17 November 2018 a national day of protest (IFOP, 2018). This was the official starting date of the Yellow Vest movement that was to take form in essentially two types of actions: one involving blocking roundabouts and highway tolls on the outskirts of small towns, and another being a march organized every Saturday in mid-size and large cities (i.e. Paris). Can participation in these actions be explained by social media use?

While the work of McPhail and Miller (1973) suggests an affirmative answer, research addressing the impact of social media use on collective action is mixed (for a review see Akfirat et al., 2020; Kende et al., 2016; Priante et al., 2018). For example, Schumann and Klein (2015) showed that online participation can sometimes decrease actions offline, a phenomenon known as slacktivism. Still, they conclude from their laboratory studies that under natural conditions where social media use reinforce a sense of belonging, it may very well promote offline collective action.

Studying students protest in Hong Kong, Lee et al. (2017) found that social media use predicted participation in the protest movement. Moreover, the effects of social-psychological variables such as efficacy on collective action were mediated by social media use. However, one limitation of their study was that: "Among the social psychological factors, this study also does not have a variable capturing the notion of identity" (p. 467). they did not measure identification as a predictor. Nevertheless, from this perspective, social media use can be hypothesized to predict participation in collective action but research is needed to determine how social identity may relate to social media use and collective action.

However, research on opinion-based group by McGarty and colleagues (2013) supports the view that social identity can function as a critical mediator of the effect of using new communication technologies (see also Smith, Blackwood, \& Thomas, 2019). In a 
detailed analysis of the Arab Spring, they specifically argue that if social media enables the formation of a new social identity that challenges the existing social order, it could motivate collective action. This analysis seems to fit well with the case of the Yellow Vest movement.

An undeniable achievement of this movement was the creation of a new and highly symbolic social identity, the Yellow Vest identity. On 24 October 2018, Ghislain Coutard posted a video convincing people to display a high visibility jacket on their cars' dashboard for a week as a sign of dissatisfaction with the new government policies (Marchesini, 2018). This idea was ingenious and far from being costly as since 2010, all French drivers are required by law to carry a high visibility jacket in the car in case of emergency. By the end of October and five million views later, the jacket has become the identity of the movement. The visibility jacket rapidly became the symbol of people who are in social and economic distress, and are engaged in anti-government protest (Beneletti, 2018). In other words, a new and highly salient intergroup context was created. Given that group identity can become salient during computer-mediated communication (Reicher, Spears \& Postmes, 1995), and given that when people share their opinions on social media platforms, this constitutes for McGarty et al. (2013), a basis for developing new collective identities and forming opinion-based groups, one can expect that the Yellow Vest identity will mediate the effect of social media use on collective action. This hypothesis will be examined in Study 2.

\subsection{Ethical and methodological statement.}

The studies were conducted in accordance with the 1964 Helsinki declaration (WMO, 1964) and its later amendments, the ethical principles of the French Code of Ethics for Psychologists (CNCDP, 2012), and the 2016 APA Ethical Principles of Psychologists and Code of Conduct (APA, 2017). Data underlying these findings are openly available at https://osf.io/mvsa7/?view_only=bfa84a9fc19f4f15ad5a23330ed1723b

\section{Study 1}


Study 1 tested the hypothesis that the Yellow Vest identity can predict the behavioral intention to take part in normative and non-normative collective actions. To do so, we used data from two studies conducted in France between November of 2018 and February of 2019 and published elsewhere (ANONYMIZED CITATION). Here, we focused on different variables than the ones investigated in the previous research. The studies were conducted on both general population (Study 1a) and student (Study 1b) samples, while including established predictors of intentions to engage in collective action such as political orientation, income, and gender. Thus, these first analyses should provide for a robust test of whether identification with the Yellow Vest constitutes a proximal predictor of intention to take part in normative and/or non-normative collective actions.

\subsection{Study $1 a$}

\subsubsection{Method}

Participants. This first study used a cross-sectional design among the general population. The data were collected between 12 December 2018 and 12 January 2019. The study was an online questionnaire disseminated on social media. The sample consisted of 776 French individuals from the general population ( $28.48 \%$ male, $50.39 \%$ female, $21.13 \%$ unreported; $M_{\text {age }}=32.02, S D=15.19$ ) allowing to detect $b=.1$ (smallest size of interest set to avoid correlation ambient noise, see Lykken, 1968) links between measures with $80 \%$ power given an alpha level set at .05 .

\subsubsection{Materials and Procedure}

The questionnaire included measures of Loss of Significance (Webber et al., 2018) and anomia (Lytkina, 2015), which were not used in the present investigation. Rather, our reanalysis was conducted using the following variables (scale items can be accessed at https://osf.io/mvsa7/?view_only=bfa84a9fc19f4f15ad5a23330ed1723b). 
Yellow Vest identification. Based on past research, a single item measure of identification with the Yellow Vest was used (see Postmes et al., 2013; 7-point Likert, from 1 'not at all' to 7 'completely', $M=3.82, S D=2.17)$.

Activism-Radicalism Intentions Scale. A modified version of the Activism-Radicalism Intentions scale (Moskalenko \& McCauley, 2009; see Scarcella et al., 2016) was used to measure behavioural intentions to display activism ('I could join the Yellow Vests'; $M=2.25$, $S D=1.02$ ) and radicalism ('I could still support the Yellow Vests even if they sometimes use violence'; $M=1.97, S D=.88)$. Responses to eight items in total were on a four-point scale ranging from 'very unlikely' to 'very likely'.

Intentions to engage in Armed Struggle. Two more items were adapted from Moskalenko and McCauley (2009) and tapped into intentions to engage in armed struggle for the Yellow Vest (four-point response scale from 'very unlikely' to 'very likely', $M=1.45, S D$ $=.64)$.

Non-Normative collective action. Seven-item scale assessing intentions to engage in non-normative were designed from real-life examples of actions displayed by the Yellow Vest (e.g. 'I could barricade roundabouts', 7-point Likert, from 1 'completely disagree' to 7 'completely agree', $M=3.31, S D=1.85)$.

Political orientation. Participants indicated their political orientation (on a scale from 1 'far-left' to 9 'far-right', $M=4.21, S D=1.88$ ). Political extremism scores were also computed from this measure (distance between participant's score and the scale's midpoint).

Demographics. Participants were asked to indicate their gender, age, and annual income (from 'less than 30,000€' coded as 1 to 'more than $120,000 €$ 'coded as 5, $M=1.70$, $S D=.88) .50 .6 \%$ of participants declared a less than $30,000 €$ income, $34.2 \%$ earning between 31,000 and $60,000 €, 11 \%$ between 61,000 and $90,000 €, 2.7 \%$ between 91,000 and $120,000 €$ and $1.4 \%$ more than $120,000 €$. 


\subsubsection{Results}

Collective action scores. Exploratory factor analyses were conducted on the four measures of collective action to compute composite scores. We used a Maximum Likelihood extraction with Promax rotation. It yielded an adequate, two dimension solution $(K M O=.95$; Bartlett's $\chi^{2}(136)=8076, p<.001 ; 58.02 \%$ of total explained variance; see Appendix II). The first factor corresponded to intentions to engage in non-violent collective action $(\alpha=.90)$ while the second factor aggregated intentions to engage in violent collective action $(\alpha=.87)$. Sum scores of z-transformed items were computed accordingly to create two variables for the main analysis.

Hypothesis test. As predicted, identification with the Yellow Vest was strongly associated with both violent, $r(775)=.72, p<.001$. and non-violent collective action, $r(775)$ $=.82, p<.001$. To provide further support for this correlational link. regression analyses were conducted to control for demographics, political orientation and political extremism. After including the controls, Yellow Vest identification still was strongly related to intention for violent, $\beta=.67, p<.001$ and non-violent collective action, $\beta=.77, p<.001$ (see Table 1).

[Table 1 here]

Political orientation. Among the pattern of correlations identified in Appendix 3., it is worth noting that right-wing affiliation was negatively related to non-violent and violent collective action, $r(775)=-.16, p<.001$ and $r(775)=-.30, p<.001$ respectively. Also, political extremism was positively associated with both non-violent $r(775)=.21, p<.001$ and violent collective action $r(775)=.34, p<.001$. These results are in line with the literature showing that left-wingers and extremists typically display stronger intentions to engage in collective action (see Jost et al., 2017). Yet, identification with the Yellow Vest, the strongest predictor of collective action intentions, did not correlate with political orientation, $r(775)=-$ $.06, p=.15$. 


\subsection{Study $1 b$.}

\subsubsection{Participants}

In the subsequent study, we sought to provide further support for the link between social identity and collective action. The data comes from an experimental design manipulating loss of significance salience which was unrelated to the present hypotheses. Undergraduates from a Parisian university were randomly to one of two experimental conditions $\left(N_{\text {control }}=258 ; N_{\text {LoS }}=253\right)$. Computerized surveys were disseminated to the undergraduate students from February the $7^{\text {th }}$ of 2019 to February the $14^{\text {th }}$ of 2019 . After assessing that conditions did not moderate the links between Identification to the Yellow Vest and the outcome measures (all $d^{\prime}$ 's $<.10$, all $p \mathrm{~s}>.10$ ), we proceeded to analysis of the merged dataset $\left(N=511 ; 9.1 \%\right.$ male, $1.3 \%$ unspecified, $\left.M_{\text {age }}=19.39, S D=3.04\right)$

\subsubsection{Materials and Procedure}

Participants were asked to provide the same demographic information as in Study 1a (gender, age and income, $M=1.84, S D=.91)$, measure of political orientation $(M=4.28, S D$ $=1.24)$ and of identification with the Yellow Vest $(M=2.83, S D=1.67) .42 .1 \%$ of participants declared a less than $30,000 €$ yearly income, $38.9 \%$ earning between 31,000 and $60,000 €, 13.3 \%$ between 61,000 and $90,000 €, 4.3 \%$ between 91,000 and $120,000 €$ and $1.4 \%$ more than $120,000 €$. Similarly, activism $(M=1.86, S D=.79, \alpha=.89)$, radicalism $(M=1.65$, $S D=.73, \alpha=.80)$, intentions to engage in non-normative collective action $(M=2.21, S D=$ $1.40, \alpha=.91)$ and in armed struggled $(M=1.22, S D=.49, r=.65, p<.001)$ were all measured using the same scales as in Study 1a.

\subsubsection{Results}

Collective action scores. Once again, we conducted factor analyses on the four measures of collective action using Maximum Likelihood extraction with Promax rotation. This time, it yielded a three dimension solution $\left(K M O=.93\right.$; Bartlett's $\chi^{2}(136)=6016.07, p<$ 
$.001 ; 61.74 \%$ of total explained variance). Unlike with the previous general population sample, participants in this sample (students) further distinguished between non-violent legal action (Factor 1; including items pertaining to support for a violent/illegal movement, which is not illegal in itself in France; $\alpha=.87$ ), illegal non-violent collective action (Factor 2; aggregating almost all the items from the non-normative collective action measure; $\alpha=.91$ ), and intentions to engage in outright violent action (factor $3 ; \alpha=.80$ ). Sum scores of $z$ transformed items were computed for the three variables.

Hypothesis test. As in Study 1a, higher identification with the Yellow Vest was strongly associated with both non-violent legal, $r=.72, p<.001$. and illegal collective action, $r=.57, p<.001$. However, among this sample, identification with the Yellow Vest was only moderately tied with intentions to engage in violent collective action, $r=.38, p<.001$. Regression analyses confirmed the robustness of these findings: the link between identification with Yellow Vest and behavioral intentions remained strong in two cases, $\beta=$ $.69, p<.001$ for non-violent legal collective action and $\beta=.52, p<.001$ for non-violent illegal action, and moderate in the other, $\beta=.36, p<.001$ for violent collective action (see Table 2). Only weak effects were observed for other predictors.

[Table 2 here]

Political orientation. As in Study 1a, right-wing affiliation was negatively correlated to non-violent legal, $r(775)=-.29, p<.001$, non-violent illegal, $r(775)=-.28, p<.001$ and violent collective action, $r(775)=-.21, p<.001$. Similarly, political extremism was associated positively with non-violent legal, $r(775)=.16, p<.001$, non-violent illegal, $r(775)=.18, p<$ .001 and violent collective action, $r(775)=.15, p<.001$. Contrary to Study 1a, however, identification with the Yellow Vest was related to left-wing affiliation, $r(775)=-.27, p<$ .001 .

\subsection{Discussion}


Data from two large samples showed that Yellow Vest identification is a robust predictor of intentions to engage in collective action, both normative and non-normative, ranging from a medium to strong effect size. Unlike political orientation and political extremism for which the effects were consistent but weaker than the effect of the identity, demographic factors we measured did not have consistent links with behavioral intentions. Moreover, political extremism was not more strongly related to collective actions than political orientation itself. Study 1 did not provide strong consistent support for the role of political affiliation or political extremism in predicting intentions to get involved in the Yellow Vest movement. It is possible that when a movement creates a new and highly distinctive identity, political affiliation itself becomes largely irrelevant to the explanation of collective behavior.

It must also be noted that among the sample composed of undergraduate students, the link between identification to the Yellow Vest and violent intentions was the lowest $(r=.38$, almost twice as low as in the first sample). Though this might be attributable to the difference in items from the composite scores, it may also be due to qualitative differences between the samples as to what prototypical content best describes the Yellow Vest. In other words, the very representation of what is or is not the Yellow Vest identity might differ across marked sociological groups (general population vs. urban educated youth). Despite these differences in meaning, the extent to which individuals identify with the Yellow Vests seems the most important factor to predict their intention to take part in collective action.

\section{Study 2}

The aim of Study 2 was two-fold: (1) to provide a conceptual replication of the link between social identity and collective action in context of the Yellow Vest, and (2) test whether higher social media use may be the underpinning of protest behavior via identity 
building. As in Study 1, we also explored to role of demographic predictors and political orientation.

In addition to the role of political orientation, we considered the role of some core beliefs about economic and social inequality that have been shown in past research to be critical in explaining socio-political involvement and activism (Guimond, 2003). Social change involves mobility of groups in society, and thus, beliefs about the legitimacy of existing social and economic inequalities can be expected to have a large bearing on sociopolitical involvement (Kluegel \& Smith, 1986). Beliefs about the legitimacy of the intergroup relations have always been central in the social identity perspective and as Jetten et al. (2020) have stressed, it is the perception of the illegitimacy of inequality that motivates lower status groups to challenge the status quo. Past research has shown with cross-sectional and longitudinal evidence, and using both self-reports and observed level of activism, that beliefs about the legitimacy of economic inequality (reasons for poverty, unemployment) predict activism and support for a broad range of social movements (Guimond, 1995; Guimond \& Palmer, 1996). From this evidence, one can hypothesize that people active in the Yellow Vest movement may be motivated by a system-blame ideology, the belief that there are systemic causes to poverty and unemployment, and that the poor and the unemployed themselves are not to blame. If this is the case, one can then wonder about the mobilization potential of such core ideological beliefs relative to that of self-categorization as a Yellow Vest. Thus, a final aim of Study 2, of a more exploratory nature, will be to (re)examine this issue about the relative role of identity and ideology in accounting for individual participation in collective action.

\subsection{Methods}

Participants were 562 French residents recruited through a Facebook page dedicated to the study and through personal networks. The participation involved completing an online 
survey which took around 10 minutes to complete. While the participation was voluntary, one 50 Euro voucher was drawn to a random person who participated. The sample consisted of slightly more women than men (57.9\% women, $41.5 \%$ men, $0.6 \%$ prefer not to say or other) aged between 24 and 74 years old $(\mathrm{M}=47.6, \mathrm{SD}=12.97)$.

This time, we measured identification with the Yellow Vest following the one item operationalization utilized in national surveys (ELABE, 2018). Namely, participants responded whether they (1) think of themselves as being a Yellow Vest, (2) support the Yellow Vest but are not a part of it, or (3) do not support the VY. We reverse-coded this item so that higher score indicated higher identification with the movement. Unlike in Study 1a and $1 \mathrm{~b}$, we also measured collective action, by considering past protest behavior (and not simply the intention). Participants were asked to report how many days out of 30 they participated in the protests on roundabouts. To measure the influence of social media in shaping the Yellow Vest identity, participants reported how often they used social media (e.g., Facebook or Twitter) to stay up to date with news regarding the Yellow Vest $(1=$ never, $2=$ rarely, $3=$ once per week, $4=$ every day). This measure was not an 'active' measure of online involvement with the Yellow Vest movement (e.g. sharing/liking Yellow Vest political posts or news). Indeed, to the extent that seemingly trivial online behaviours could be considered as online activism, we opted for using 'passive' measures of news uptake to avoid confounding with our outcome variable (i.e. offline activism, see Greijdanus et al., 2020). Finally, as with previous two studies, we included a number of control variables including political orientation measured on a 10-point Likert, from 1 'extreme-left' to 10 'extremeright'. Given the weak results observed in Study 1 concerning the prediction of behavioral intentions with political orientation, Study 2 sought to improve our measurements of ideological beliefs by including measures of system-blame ideology consistently found in previous research to predict observed as well as self-reported level of activism (Guimond, 
2003). Participants were asked to indicate their level of agreement $(1=$ strongly disagree; $5=$ strongly agree) with a series of statements taken from Guimond (1995) about the causes of poverty and unemployment. Four items were used to construct a scale of system-blame ideology with items attributing inequality to systemic factors (e.g., "The main reason for poverty is exploitation by the rich"). Two items measured the tendency to attribute poverty and unemployment to chance (“Anybody can be poor, it's simply a question of bad luck"). Including these items is important to confirm that it is not simply a tendency to put the blame on any external factors that is important in collective mobilization but a tendency to blame the system. In terms of demographics, participants indicated their gender, age and level of education on a list of 12 types of qualifications. These were then recoded into a six-point item with a higher score indicating higher education level. Income was not measured in this study, but we used education level as a proxy for social status.

To evaluate whether the sample size of this study was adequate to detect even small effect sizes, we conducted a sensitivity power analysis. The analysis was conducted in G*Power (Faul et al., 2007) using the linear multiple regression method. With six predictors of collective action (Yellow Vest identification, social media use, political orientation, education, age, and gender) our sample size was sufficient to detect even a small effect size of Cohen's $\mathrm{f}^{2}=.02$, assuming $80 \%$ power and alpha level of .05 .

\subsection{Results}

To test our hypotheses, we first examined the correlation between Yellow Vest identification and collective action. Consistent with Studies 1a and 1b, higher Yellow Vest identification was related to more frequent attendance at the protests, $r(558)=.42, p<.001$, although the strength of this relationship was weaker than in previous studies. Higher social media use was also related to stronger Yellow Vest identification, $r(556)=.42, p<.001$ and to 
more frequent protesting, $r(556)=.19, p<.001$. Political orientation was not related to Yellow Vest identification, $r(538)=-.01, p=.839$.

We proceeded by first entering the demographic predictors and political orientation into a linear regression model predicting collective action. Only education was a significant predictor of collective action with those with lower education reporting more frequent protest behavior, $\beta=-.21, t=-4.80, p<.001$ whereas age, gender and political orientation were nonsignificant predictors of protest behavior (see Table 3, Model 1). This model was statistically significant but only explained $4 \%$ of the variance in protest behavior. In the subsequent model, we added social media use as an additional predictor. This model confirmed the previously reported positive link between social media use and protest behavior, even when controlling for demographic variables and political orientation (see Table 3, Model 2).

Finally, entering Yellow Vest identification as a predictor increased the explained variance to $19 \%$. While education remained a significant predictor of collective action $\beta=-.11, t=-2.53$, $\mathrm{p}=.012$, social media use was no longer a significant predictor $\beta=.02, t=.44, \mathrm{p}=.660$. The final model suggests that Yellow Vest identification was the strongest predictor of collective action with stronger Yellow Vest identification predicting more frequent protest participation, $\beta=.40, t=8.93, \mathrm{p}<.001$ (see Table 3, Model 3).

[Table 3 here]

To corroborate our mediational hypotheses, we tested the whether the collective action was related to higher social media use, which in turn was related to higher Yellow Vest identification (see Figure 1). We have carried out a mediation analysis using sem function in the lavaan R package (bootstrap $n=10,000$ ). Due to missing data, $n=557$ observations were used to compute the estimates. Unstandardized coefficients are reported in text whereas the standardized coefficients can be viewed in Figure 1. More frequent social media use was related to stronger Yellow Vest identification, $b=.34$, se $=.03, p<.001,95 \%$ CI $[.27, .41]$ 
which in turn was related to more frequent protest behavior, $b=4.03$, se $=.35, p<.001,95 \%$

CI $[3.37,4.73]$. Controlling for Yellow Vest identification, there was no effect of social media use on collective action, $b=.17$, se $=.29, p=.548,95 \%$ CI [-.45, .69], but the bootstrapping analysis based on $n=10,000$ samples showed that there was an indirect effect of social media on collective action via Yellow Vest identification, $b=1.38$, se $=.18, p<.001,95 \%$ CI [1.05, 1.76]. Therefore, higher social media use to check news relating to the protest was associated with higher Yellow Vest identification which, in turn, further fostered collective action. A test of an alternative model proposed by Lee et al. (2017) suggesting that social media use can mediate the effect of social identity on collective action provided no supportive evidence as the indirect effect of Yellow Vest identification on collective action via social media was nonsignificant, $b=.09$, se $=.17, p=.609,95 \%$ CI $[-.25, .42]$.

[Figure 1 here]

The above results indicate that political orientation is not related to the participation in collective action within the Yellow Vest movement. However, consistent with past research, a system-blame ideology reflecting a tendency to blame systemic factors to explain unemployment and poverty is significantly correlated with participation in collective action, $\mathrm{r}(555)=.19, \mathrm{p}<.001$. On the other hand, the tendency to blame bad luck does not predict collective action, $\mathrm{r}(555)=.07, \mathrm{p}=.104$. We have re-run the regression analyses to include blame and chance ideologies. After controlling for demographics (education, age, gender), political orientation and social media use, higher system blame ideology was related to more frequent protest behaviour, $\beta=.17, t=3.44, p<.001$, whereas chance blame was a nonsignificant predictor of collective action, $\beta=.05, t=1.06, p=.291$. However, once Yellow Vest identification was added into the subsequent model, system blame ideology was no longer a significant predictor of collective action, $\beta=-.06, t=-1.12, p=.264$ while Yellow 
Vest identification remained the strongest predictor of collective action, $\beta=.42, t=8.15, p$ $<.001$,

\subsection{Discussion}

Study 2 conceptually replicated the finding linking the role of identification in motivating participation in Yellow Vest protests. Identifying as a Yellow Vest was more important than political orientation or demographics in predicting how frequently the French citizens participated in the local Yellow Vest protests organized at the roundabouts across France. Furthermore, the data supports the notion that Yellow Vest identification was built and driven, at least partly, by social media use. Increased use of social media to stay informed about the Yellow Vest-related news was related to increased identification as a Yellow Vest, which in turn, was associated with more frequent protest participation. This is consistent with McGarty et al. (2013)'s analysis of the Arab Spring. They argued that "communication technologies enable the formation of new social identities that can challenge existing social orders by promoting the growth of a social movement" (p. 725). This is exactly what happened in France and our data suggest that the creation of the new Yellow Vest identity is the critical social-psychological process that allowed the growth of the movement. In contrast, there was no support for the view that social-psychological predictors of protest are now secondary, given the development and use of new communication technologies (see Akfirat et al., 2020; Lee et al., 2017).

\section{General discussion}

The present research offers three main contributions. First, regardless of ideology and political orientation, identification as a Yellow Vest is a major factor accounting for the formation of an intention to get involved in this movement and for the actual participation in

collective action across France, as reported by the participants. Second, social identity appears important to understand both normative and non-normative collective action, something that 
was not clearly established in past research. Finally, the critical role of social media use in fostering collective protest is accounted for by social identity. We will discuss each of these findings in turn.

\subsection{Social identity: behaving as a group member}

On 21 September 2019, the Yellow Vest movement entered its $45^{\text {th }}$ consecutive week of protests and mobilization. In France and worldwide, very few protest movements succeed in keeping the momentum for such a long time. What can explain the involvement of individuals within this movement? Several answers have been given to that question but most of them may have missed the obvious. Many people in France came to define themselves as a Yellow Vest and this self-categorization was a powerful factor accounting for why some individuals got into the action while others did not. In Study 1, Yellow Vest identification was strongly predictive of the intention to participate in collective action in student and general population samples. In Study 2, self-categorization as a Yellow Vest was strongly predictive of the actual participation in collective action as reported by the participants. The fact that the relationship found in Study 2 is less strong than in Study 1 fits with the idea that explaining actual behaviour is more difficult than explaining behavioural intention. Although intention is probably the strongest known predictor of actual behaviour (Sheeran, 2002), intention and behaviour do not always go hand in hand: many of those who indicated their intention to take part in collective action will not necessarily do so. For this reason, it is methodologically important to test the same relations with regards to intentions and behaviors. Of course, the main interest of the present research stems from the fact that intentions and behaviors are measured in the context of an on-going real protest movement. In contrast, past research in social psychology, especially those conducted in a laboratory setting, has difficulty measuring intentions or behaviors that have a high correspondence with socially real episodes of protest. For example, in an important longitudinal analysis, Thomas et al. (2020) confirmed the role of 
social identity as an antecedent of collective action using measures such as "I have considered participating in demonstrations on behalf of my ethnic group" (p. 5). Yet, at the time of the study there were no protest movements capturing the mind of the population and answers to such dependent variables are hypothetical by nature. Obtaining converging evidence in the context of the Yellow Vest movement complements these results and reinforces their theoretical relevance.

The fact that political orientation was weakly related to intentions in Study 1 and unrelated to the measure of collective action in Study 2 also fits with the intention versus actual behaviour asymmetry. In Study 1, people to the left of political spectrum were more willing to take part in a movement that advocate change comparing than those leaning to the right. But in Study 2, when asked about actual participation in roundabout protests, we found that collective action behaviour was not related to political orientation. This is consistent with many previous reports on the Yellow Vest (Alexandre et al., 2019; Lorriaux, 2018). Despite the fact that in France, political orientation is often found to drive people's attitudes and behaviors (e.g., Urbanska \& Guimond, 2018), this is not the case in terms of actions within the Yellow Vest movement. This suggest that in terms of this movement, it was identity first and ideology second: the superordinate identity of the yellow vest allowed the bonding of individuals from diverse ideological backgrounds behind a common cause. This conclusion is suggested also by the results of Study 2 concerning beliefs about the legitimacy of economic inequality. Replicating past research, blaming the system to explain poverty and unemployment is a significant predictor of participation in collective action (see Guimond, 2003). Contrary to the view that the Yellow Vests are blaming everything but themselves for their own economic problems, the results also showed that explaining inequalities by external factors that are outside of anybody's control, such as chance or bad luck, do not mobilize to action. Still, Study 2 showed that a system-blame ideology is far from being as important as 
Yellow Vest identification as a predictor of collective action. In fact, our analysis indicated that once Yellow Vest identification is taken into account, there are no ideological beliefs that remain predictive of participation in collective action. Thus, the present research provides support for the idea that the creation of a shared social identity in and of itself plays an important role in galvanizing individuals to join new causes.

Concerning the structural basis of the movement, income is not related to the intention to take part in collective action in Study 1 but we find an important link with level of education in Study 2, and this link is independent of other variables, even identification with the Yellow Vest. Past research has shown that people involved in social movements, ghetto riots, urban violence or even terrorism were more highly educated than those not involved (see Guimond, 2003; Smith et al., 2019). Here, we find the reverse. People active in roundabouts had a lower level of education compared to those who were less active or not participating at all. This is a critical finding because education confers not only status but also an assumed legitimacy to existing social arrangements. As such, the Yellow Vest movement can be seen, in part, as challenging this legitimacy and as giving a voice to those who do not usually take part in major social and political debates. Thus, our findings lend support to a class basis of the Yellow Vest, as hypothesized by Jetten et al. (2020).

\subsection{Collective action and political violence}

Study 1 provided a novel contribution to the social psychological literature by providing a systematic test of a link between social identification and the intention to use normative/non-violent tactics as well as non-normative and violent ones. While past research lead to the assumption that social identity is important for both (Becker \& Tausch, 2015), there has been very few studies that have directly compared across different samples the ability of social identity to predict involvement in violent as oppose to non-violent action. The results obtained here are clear: those who identify with the Yellow Vest have a greater 
willingness to engage in both normative and non-normative actions. This is in stark contrast to the role of group-based emotions or collective efficacy that were shown by Tausch and Becker (2011) to operate differently in normative as oppose to non-normative collective action.

As such, the special status accorded to social identity by van Zomeren et al. (2008), relative to other determinants of group action, is confirmed. However, a further important implication is to provide support for the research strategy advocated by Smith et al. (2019), to "study extremist groups as group first, and as extremists second" (p. 5). If social identity was important only to predict the intention to engage in normative actions, then one would conclude that non-normative collective action require a different analysis. Because this is not the case, the results suggest that theories about how groups form and how social identity develops may be important for any social movement, regardless of its level of radicalism. Indeed, social identification was a robust and independent predictor of radicalism measures which included intentions to retaliate against innocent civilians and to engage into an armed struggle for the movement (see Appendix 3 for correlations). This shows how social identification may also predict actions that extend beyond the group's prototypical behavioural repertoire in terms of activism or radicalism.

These findings do not square well with the persistent tendency among psychologists to consider that radicalism must somehow be born out of a defect in the cognitive or emotional system of the individual. We find strong evidence that stronger identification with the Yellow Vest movement was related to willingness to engage in more extreme political actions. Given the levels of violence observed in the movement, this perspective is entirely consistent with research on crowd dynamics (see Drury \& Reicher, 2000 ; Reicher, 1996 ; Stott et al., 2018). The Yellow Vest started out advocating normative collective actions but quickly came to the conclusion, when confronted with an increasingly strong and brutal police force, that they did 
not have the choice but to move toward more radical actions. This is also the perspective adopted by Sageman (2017) in his attempt to understand why various groups across history have turned to political violence and terrorism. He found that the social identity perspective provides an adequate account and see no need to postulate the existence of indoctrination, mental illness or brainwashing as additional processes. Rather, there is a need to consider that political mobilization evolves over time, and that when peaceful protests are met with continued repression and are perceived as such, the likelihood that group members will start advocating the use of more radical actions increases.

\subsection{Social media, political orientation and ideology}

A third and final contribution of the present research is to show how an increasing number of accounts of protest movements that rely on the role of social media platforms can benefit from taking into account the mediating role of social identity. In Study 2, we found a significant link between social media use and participation in collective action. Within the Yellow Vest movement, those who took the streets in roundabouts and highway tolls across France were heavy users of social media platforms. This is consistent with McPhail and Miller (1973)'s theoretical analysis of the role of communication in allowing for collective gathering and confirm many past analyses about the major role that new communication devices are playing in social and political movements. However, there is also a new takehome message in our results: social media platforms will result in offline collective action when they create a new social identity.

This is in line with the social psychological model of radicalization outlined by Smith et al. (2019). They distinguish between three main factors that are causally related: social interactions (including online interactions) lead to social identity formation that lead to (violent) group actions (see also McGarty et al., 2013). Research so far provide largely indirect evidence for this model. In Study 2, because self-categorization as a Yellow Vest 
mediated the effect of social media use on the participation in collective action, this is direct support for this model. Of course, given the correlational nature of these data, there is a need for further research that can allow a causal ordering of the variables. For now, the critical message is that social media use may not be important simply because it allows for the communication of information but because it can speed up the development of a new social identity. When people share and validate their experiences through social media, this increases their sense of belonging creating a shared social identity (Smith et al., 2019). This identity then becomes a strong basis for mobilization around collective action, normative or non-normative ones. There is also evidence showing that the degree to which individuals perceive shared moralization of grievances on social media predicts subsequent violence of collective action (see Mooijman et al., 2018). To the extent that feeling identified to a common ingroup increases sharedness of experiences and of group-based emotions (e.g. Kessler, \& Hollbach, 2005), emergent social identities like the Yellow Vest may constitute a catalyser for radicalization in and of themselves.

Given the existence of feedback loop, considering that the model in Figure 1 may work in reverse would also make theoretical sense. Participating in collective action in roundabouts with fellow ingroup members can make a self-definition as a Yellow Vest more important (see Becker \& Tausch, 2015; Drury \& Reicher, 2000). This new identity may then motivate greater social media use. Our results are also consistent with this account and we cannot deduce a causal ordering of the variables on the basis of the present data. There is however one model that receives no support, the one advocated by Lee et al. (2017) suggesting that social psychological determinants of protest behaviours have become, in the digital age, secondary to social media use. Lee et al. (2017) find support for such a model in Hong-Kong by considering group efficacy and grievances as social-psychological 
determinants. Research comparing different protest movements in different settings are needed to better understand these different results.

\subsection{Limitations and future research}

First and foremost, the present studies are inherently limited by the use of a crosssectional design at a single point in time. Repeated data collection over time would allow to directly study the intergroup dynamics shaping the movement (Stott, 2018). Future studies should employ various methodologies that allow to grasp the full depth of such dynamical social phenomena, as well as a larger protester behavioural repertoire (see Fisher et al., 2019).

Second, our measurement of social identity as a Yellow Vest was straightforward but perhaps limited. Past research has shown that social identity can have different cognitive and affective components (e.g., Ellemers et al., 1999). Future research should use multi-items measures of social identity in order to examine the relative importance of these components in the explanation of normative and non-normative collective action.

Finally, as with any correlational study, the present research cannot claim that Yellow Vest identification is a causal factor leading people to form certain intentions or to engage in a particular course of action. The reverse is possible. There are arguments to suggest, as noted above, that participating in collective action may very well increase or make more salient a given social identity. Caution should be applied to Study 2's mediation model regarding the link between social identification and social media use. Regression analyses suggest a more proximal (hence mediator) role of social identification, as attested by a loss of social media use's link with collective action when introducing identification in the model (from $p<.001$ to $p=.66)$. Still, this evidence remains statistical, and in absence of longitudinal and/or experimental corroboration for this mediation model, causality should not be inferred (Fiedle et al., 2018). These correlational data nevertheless can serve to justify the development of experimental studies that can distinguish between different models. Can using social media 
not only reinforce one's attitudes but also foster a new way of categorizing the self? Given the power of self-categorization in accounting for collective action, such causal evidence of the effect of social media use on self-categorization would raise questions about the model advocated by Lee et al. (2017). More importantly, the present research suggests that more efforts are needed to understand why some people are more likely than others to take on a new social identity and to incorporate this identity as an important part of their self-concept. Our evidence suggests that using social media platforms can be an important part of the story, but other cognitive, emotional or ideological factors may be involved. Experimental and longitudinal approaches are needed to get a better understanding of this problem.

\section{References}

Adam-Troian, J., Celebi, E., \& Mahfud, Y. (in press). 'Return of the Repressed': Exposure to Police Violence increases Protest and Self-Sacrifice Intentions for the Yellow Vests. Group Processes \& Intergroup Relations.

Akfirat, S., Uysal, M. S., Bayrak, F., Ergiyen, T., Üzümçeker, E., Yurtbakan, T., \& Özkan, Ö. S. (2020). Social Identification and Collective Action Participation in the Internet Age: A Meta-Analysis. Unpublished manuscript. doi: 10.31234/osf.io/uqb7a

Alberici, A. I., \& Milesi, P. (2016). Online discussion, politicized identity, and collective action. Group Processes \& Intergroup Relations, 19(1), 43-59.

doi:10.1177/1368430204046145

American Psychological Association. (2017). Ethical principles of psychologists and code of conduct. Retrieved from http://www.apa.org/ethics/code/index.aspx

Atran, S., Sheikh, H., \& Gomez, A. (2014). Devoted actors sacrifice for close comrades and sacred cause. Proceedings of the National Academy of Sciences, 111(50), 17702-17703. https://doi.org/10.1073/pnas.1420474111

Becker, J. C., \& Tausch, N. (2015). A dynamic model of engagement in normative and nonnormative collective action: Psychological antecedents, consequences, and barriers. European Review of Social Psychology, 26(1), 43-92.https://doi.org/10.1080/10463283.2015.1094265

Bedock, C., de Raymond, A. B., Blavier, P., Della Sudda, M., Grémion, T., Reungoat, E., ... \& Bendali, Z. (2019). Enquêter in situ par questionnaire sur une mobilisation en cours [Ecological survey-based investigation of an unfolding social movement]. Revue Francaise de Science Politique, 69, 869-892. 10.3917/rfsp.695.0869 
Bimber, B. (2017). Three prompts for collective action in the context of digital media. Political Communication, 34(1), 6-20.

https://doi.org/10.1080/10584609.2016.1223772

Blakemore, E. (2019, March 29). What was the Arab Spring and how did it spread? National Geographic [online]. Available at https:/www.nationalgeographic.com/culture/topics/reference/arab-spring-cause

Boulianne, S. (2015). Social media use and participation: A meta-analysis of current research. Information, communication \& society, 18(5), 524-538.

https://doi.org/10.1080/1369118X.2015.1008542

Brown, R.J., \& Turner, J.C. (1981). Interpersonal and intergroup behavior. In J.C. Turner \& H. Giles (Eds.,) Intergroup behavior (pp. 33-65). Basil Blackwell.

Commission Nationale Consultative de Déontologie des Psychologues. (2012). Code de Déontologie des Psychologues [Psychologists' Code of Conduct] (1996, Amended February, 2012). Retrieved from http://www.cncdp.fr/index.php/code-de-deontologie/code-dedeontologie-2012

Craig, M. A., Badaan, V., \& Brown, R. M. (2020). Acting for whom, against what? Group membership and multiple paths to engagement in social change. Current Opinion in Psychology, 35, 41-48.https://doi.org/10.1016/j.copsyc.2020.03.002

de Weerd, M., \& Klandermans, B. (1999). Group identification and political protest: Farmers' protest in the Netherlands. European Journal of Social Psychology, 29(8), 1073-1095. https://doi.org/10.1002/(SICI)1099-0992(199912)29:8<1073::AID-EJSP986>3.0.CO;2-K

Drury, J., \& Reicher, S. (2000). Collective action and psychological change: The emergence of new social identities. British journal of social psychology, 39(4), 579-604.

https://doi.org/10.1348/014466600164642

Drury, J., Stott, C., \& Farsides, T. (2003). The Role of Police Perceptions and Practices in the Development of "Public Disorder". Journal of Applied Social Psychology, 33(7), 1480-1500. https://doi.org/10.1111/j.1559-1816.2003.tb01959.x

Ellemers, N., Spears, R., \& Doosje, B. (1999). Social identity (p. 144). Blackwell: Oxford.

Faul, F., Erdfelder, E., Lang, A., Buchner, A. (2007). G*Power 3: A flexible statistical power analysis program for the social, behavioural, and biomedical sciences. Behaviour Research Methods, 39, 175-191. https://doi.org/10.3758/BF03193146

Fiedler, K., Harris, C., \& Schott, M. (2018). Unwarranted inferences from statistical mediation tests-An analysis of articles published in 2015. Journal of Experimental Social Psychology, 75, 95-102. https://doi.org/10.1016/j.jesp.2017.11.008 
Fisher, D. R., Andrews, K. T., Caren, N., Chenoweth, E., Heaney, M. T., Leung, T., ... \& Pressman, J. (2019). The science of contemporary street protest: New efforts in the United States. Science advances, 5(10), eaaw5461. 10.1126/sciadv.aaw5461

Ginges, J., Atran, S., Sachdeva, S. \& Medin, D. (2011) Psychology out of the Laboratory: The Challenge of Violent Extremism. American Psychologist, 66(6), 507-519.

https://doi.org/10.1037/a0024715

Greijdanus, H., de Matos Fernandes, C. A., Turner-Zwinkels, F., Honari, A., Roos, C. A., Rosenbusch, H., \& Postmes, T. (2020). The psychology of online activism and social movements: relations between online and offline collective action. Current opinion in psychology. https://doi.org/10.1016/j.copsyc.2020.03.003

Guerra, T., Gonthier, F., Alexandre, C., Gougou, F., \& Persico, S. (2019). Les valeurs politiques des "gilets jaunes». Retrived, January, 27-28 from: Le Monde du 27-28 janvier.Algan, Beasley, Cohen, Foucault \& Péron, 2019-ScPO Paris

Guimond, S. (1995). Niveau d'analyse dans l'étude des explications causales: Implications théoriques et socio-politiques [Level of analysis in the study of causal attribution : theoretical and socio political implications]. International Review of Social Psychology, 8, 29-54.

Guimond, S. (2003). Stigmatisation et mouvements sociaux. In J.-C. Croizet \& J.-P. Leyens (Eds.), Mauvaises reputations ( pp. 257-281). Armand Colin.

Guimond, S. (2010). Psychologie sociale: Perspective multiculturelle (Vol. 4). Editions Mardaga.

Guimond, S., \& Palmer, D. L. (1996). The political socialization of commerce and social science students: Epistemic authority and attitude change. Journal of Applied Social Psychology, 26(22), 1985-2013. https://doi.org/10.1111/j.1559-1816.1996.tb01784.x

Huang, C. (2017). Time spent on social network sites and psychological well-being: a metaanalysis. Cyberpsychology, behavior and social networking, 20, 346-354. https://doi.org/10.1089/cyber.2016.0758

IFOP pour le journal du dimanche. (n. d.). In IFOP. Retrieved January, 23, 2019, from https://www.ifop.com/publication/les-indices-de-popularite-janvier-2019/

Jetten, J., Mols, F., \& Selvanathan, H. P. (2020). How Economic Inequality Fuels the Rise and Persistence of the Yellow Vest Movement. International Review of Social Psychology, 33(1), 2. http://doi.org/10.5334/irsp.356

Jost, J. T., Becker, J., Osborne, D., \& Badaan, V. (2017). Missing in (collective) action: Ideology, system justification, and the motivational antecedents of two types of protest behavior. Current Directions in Psychological Science, 26(2), 99-108.

https://doi.org/10.1177/0963721417690633

Kelly, C., \& Breinlinger, S. (1995). Identity and injustice: Exploring women's participation in collective action. Journal of Community \& Applied Social Psychology, 5(1), 41-57. https://doi.org/10.1002/casp.2450050104 
Kende, A., van Zomeren, M., Ujhelyi, A., \& Lantos, N. A. (2016). The social affirmation use of social media as a motivator of collective action. Journal of Applied Social Psychology, 46(8), 453-469. https://doi.org/10.1111/jasp.12375

Kessler, T., \& Hollbach, S. (2005). Group-based emotions as determinants of ingroup identification. Journal of Experimental Social Psychology, 41(6), 677-685. https://doi.org/10.1016/j.jesp.2005.01.001

Kluegel, J. R., \& Smith, E. R. (1986). Social institutions and social change. Beliefs about inequality: Americans' views of what is and what ought to be. Aldine de Gruyter.

Lee, F. L., Chen, H. T., \& Chan, M. (2017). Social media use and university students' participation in a large-scale protest campaign: The case of Hong Kong's Umbrella Movement. Telematics and Informatics, 34(2), 457-469.

https://doi.org/10.1016/j.tele.2016.08.005

Lelan, Bendali, Delozière, Elek \& Gaborit, (2018, December 19). Enquête: Les gilets Jaunes ont-ils une couleur politique? [Investigation: Do the Yellow Vests have a political orientation?] L'Humanité [online]. Available at https://www.humanite.fr/enquete-les-giletsjaunes-ont-ils-une-couleur-politique-665360

Lorriaux (2018). Ce que révèlent les sondages sur l'identité des "gilets jaunes". Retrieved December, 4th, 2018 from: http://www.slate.fr/story/170766/qui-sont-gilets-jaunes-etsoutiens-portrait-robot-categories-socio-professionnelles

Lykken, D. T. (1968). Statistical significance in psychological research. Psychological Bulletin, 70(3, Pt.1), 151-159. https://doi.org/10.1037/h0026141

Lytkina, E. (2015). Anomie And Alienation In The Post-Communist Area: A Reapplication Of The Middleton Scale In Russia And Kazakhstan. Higher School of Economics Research Paper No. WP BRP, 32.

Marchesini, F. (2018). De vêtement banal, comment le gilet jaune est devenu un symbole puissant. https://www.lemonde.fr/societe/video/2018/12/14/gilets-jaunes-comment-unvetement-banal-est-devenu-un-puissant-symbole_5397438 3224.html

Marzouki, Y., \& Oullier, O. (2014). Internet search volume as a proxy approach to the Virtual Collective Consciousness. In A.D. Cheok (Ed.). Hyperconnectivity and the future of Internet communication (30 p.). Hershey: IGI Global.

Mazeau, G. (2019). Les « gilets jaunes » et la Révolution française : quand le peuple reprend l'histoire. [Yellow Vests and the French revolution : when the People re-appropriates history] In AOC «Gilets jaunes »- Hypothèses sur un mouvement (pp. 107-112). Paris : La

Découverte.

McGarty, C., Bliuc, A. M., Thomas, E. F., \& Bongiorno, R. (2009). Collective action as the material expression of opinion-based group membership. Journal of Social Issues, 65(4), 839857. https://doi.org/10.1111/j.1540-4560.2009.01627.x 
McGarty, C., Thomas, E. F., Lala, G., Smith, L. G., \& Bliuc, A. M. (2014). New Technologies, New Identities, and the Growth of Mass Opposition in the Arab Spring. Political Psychology, 35(6), 725-740. https://doi.org/10.1111/pops.12060

McPhail, C., \& Miller, D. (1973). The assembling process: A theoretical and empirical examination. American sociological review, 721-735. https://www.jstor.org/stable/2094134

McPhail, C., \& Schweingruber, D. The 1995 March for Life in Washington, DC. http://davidschweingruber.com/docs/McPhail\&Schweingruber(1998).pdf

Mooijman, M., Hoover, J., Lin, Y., Ji, H., \& Dehghani, M. (2018). Moralization in social networks and the emergence of violence during protests. Nature human behaviour, 2(6), 389. https://doi.org/10.1038/s41562-018-0353-0

Moskalenko, S., \& McCauley, C. (2009). Measuring Political Mobilization: The Distinction Between Activism and Radicalism. Terrorism and political violence, 21(2), 239-260. https://doi.org/10.1080/09546550902765508

Noiriel, G. (2019). Les gilets jaunes à la lumière de l'histoire - dialogue avec Nicolas Truong. [A historical perspective on the Yellow Vests] La Tour d'Aigues: Le Monde/Editions de l'Aube.

Postmes, T., Haslam, S. A., \& Jans, L. (2013). A single-item measure of social identification: Reliability, validity, and utility. British journal of social psychology, 52(4), 597-617. https://doi.org/10.1111/bjso.12006

Priante, A., Ehrenhard, M. L., van den Broek, T., \& Need, A. (2018). Identity and collective action via computer-mediated communication: A review and agenda for future research. New media \& society, 20(7), 2647-2669. https://doi.org/10.1177/1461444817744783

Reicher, S. D. (1996). 'The Battle of Westminster': Developing the social identity model of crowd behaviour in order to explain the initiation and development of collective conflict. European journal of social psychology, 26(1), 115-134. https://doi.org/10.1002/(SICI)1099-0992(199601)26:1<115::AID-EJSP740>3.0.CO;2-Z

Reicher, S. D., Spears, R., \& Postmes, T. (1995). A social identity model of deindividuation phenomena. European review of social psychology, 6(1), 161-198.

https://doi.org/10.1080/14792779443000049

Reicher S., Stott C., Cronin P., Adang O. (2004). An Integrated Approach to Crowd Psychology and Public Order Policing. Policing: An International Journal 27(4), 558572. https://doi.org/10.1108/13639510410566271

Sageman, M. (2017). Turning to political violence: The emergence of terrorism. University of Pennsylvania press.

Scarcella, A., Page, R., \& Furtado, V. (2016). Terrorism, radicalisation, extremism, authoritarianism and fundamentalism: A systematic review of the quality and psychometric properties of assessments. PloS one, 11(12), e0166947. https://doi.org/10.1371/journal.pone.0166947 
Schumann, S., \& Klein, O. (2015). Substitute or stepping stone? Assessing the impact of lowthreshold online collective actions on offline participation. European Journal of Social Psychology, 45(3), 308-322. https://doi.org/10.1002/ejsp.2084

Sheeran, P. (2002). Intention-behavior relations: a conceptual and empirical review. European review of social psychology, 12(1), 1-36. https://doi.org/10.1080/14792772143000003

Sherif, M., \& Predicament, I. C. (1966). Social psychology of intergroup conflict and cooperation. Haughton and Mittlin.

Smith, L. G., Blackwood, L., \& Thomas, E. F. (2019). The Need to Re-focus on the Group as the Site of Radicalization. Perspectives on Psychological Science, 1-68.

https://doi.org/10.1177/1745691619885870

Stathi, S., Vezzali, L., Waldzus, S., \& Hantzi, A. (2019). The mobilizing and protective role of national identification in normative and non-normative collective action. Journal of Applied Social Psychology, 49(9), 596-608. https://doi.org/10.1111/jasp.12619

Stott, C., Ball, R., Drury, J., Neville, F., Reicher, S., Boardman, A., \& Choudhury, S. (2018). The evolving normative dimensions of 'riot': Towards an elaborated social identity explanation. European Journal of Social Psychology, 48(6), 834-849.

https://doi.org/10.1002/ejsp.2376

Stott, C., \& Pearson, G. (2007). Football 'hooliganism': policing and the war on the 'English disease'. Pennant Books.

Stott, C., Radburn, M., \& Savigar, L. (2020, in press) Crowd Theory, Communication and Policing. In Giles, H., Maguire, E., \& Hill, S. (Eds). The Handbook of Policing,

Communication and Society. Rowan \& Littlefield

Tajfel, H. E. (1978). Differentiation between social groups: Studies in the social psychology of intergroup relations. Academic Press.

Tajfel, H., Turner, J. C., Austin, W. G., \& Worchel, S. (1979). An integrative theory of intergroup conflict. Organizational identity: A reader, 56-65.

Tausch, N., Becker, J. C., Spears, R., Christ, O., Saab, R., Singh, P., \& Siddiqui, R. N. (2011). Explaining radical group behavior: Developing emotion and efficacy routes to normative and nonnormative collective action. Journal of Personality and Social Psychology, 101(1), 129148. https://doi.org/10.1037/a0022728

Thomas, E. F., Zubielevitch, E., Sibley, C. G., \& Osborne, D. (2020). Testing the social identity model of collective action longitudinally and across structurally disadvantaged and advantaged groups. Personality and Social Psychology Bulletin, 46(6), 823-838.

https://doi.org/10.1177/0146167219879111 
Troian, J., Arciszewski, T., \& Apostolidis, T. (2019). The dynamics of public opinion following terror attacks: Evidence for a decrease in equalitarian values from Internet Search Volume Indices. Cyberpsychology: Journal of Psychosocial Research on Cyberspace, 13(3). https://doi.org/10.5817/CP2019-3-4

Turner, J. C. (1982). Towards a cognitive redefinition of the social group. Social identity and intergroup relations, $1(2), 15-40$.

Turner, J. C., Hogg, M. A., Oakes, P. J., Reicher, S. D., \& Wetherell, M. S. (1987). Rediscovering the social group: A self-categorization theory. Basil Blackwell.

Turner, J. C., Oakes, P. J., Haslam, S. A., \& McGarty, C. (1994). Self and collective: Cognition and social context. Personality and social psychology bulletin, 20(5), 454-463. https://doi.org/10.1177/0146167294205002

Turner, J. C., \& Reynolds, K. J. (2001). The social identity perspective in intergroup relations: Theories, themes, and controversies. Blackwell handbook of social psychology: Intergroup processes, 4, 133-152.

Turner, J. C., \& Reynolds, K. J. (2012). Self-categorization theory. Handbook of theories in social psychology, 2(1), 399-417.

Urbanska, K., \& Guimond, S. (2018). Swaying to the extreme: Group relative deprivation predicts voting for an extreme right party in the French presidential election. International Review of Social Psychology, 31(1).

https://doi.org/10.5334/irsp.201

Van Prooijen, J. W., \& Krouwel, A. P. (2019). Psychological Features of Extreme Political Ideologies. Current Directions in Psychological Science, 28(2), 159-163.

https://doi.org/10.1177/0963721418817755

Van Zomeren, M., Postmes, T., \& Spears, R. (2008). Toward an integrative social identity model of collective action: A quantitative research synthesis of three socio-psychological perspectives. Psychological bulletin, 134(4), 504. https://doi.org/10.1037/0033$\underline{2909.134 .4 .504}$

Webber, D., Babush, M., Schori-Eyal, N., Vazeou-Nieuwenhuis, A., Hettiarachchi, M., Bélanger, J. J., Moyano, M., Trujillo, H. M., Gunaratna, R., Kruglanski, A. W., \& Gelfand, M. J. (2018). The road to extremism: Field and experimental evidence that significance lossinduced need for closure fosters radicalization. Journal of Personality and Social Psychology, 114(2), 270-285. https://doi.org/10.1037/pspi0000111

Wells, G. L., \& Windschitl, P. D. (1999). Stimulus sampling and social psychological experimentation. Personality and Social Psychology Bulletin, 25(9), 1115-1125. https://doi.org/10.1177/01461672992512005

World Medical Organization. (1964). Recommendations guiding physicians in biomedical research involving human subjects. 
Wright, S. C., Taylor, D. M., \& Moghaddam, F. M. (1990). Responding to membership in a disadvantaged group: From acceptance to collective protest. Journal of Personality and Social Psychology, 58(6), 994-1003. https://doi.org/10.1037/0022-3514.58.6.994

Table 1

Regression analyses testing the effect of identification with the Yellow Vest upon behavioural intentions to engage in collective action adjusted for age, gender, income, political orientation and political extremism (Study 1a, outcomes: Model $1=$ violent collective action, Model 2 = non-violent collective action, $N=612$ )

\begin{tabular}{|c|c|c|c|c|c|c|}
\hline Predictors & $t$ & $F$ & $d f$ & $\beta$ & $R^{2}$ & $p$ \\
\hline Model 1 & & $161.29 * * *$ & $\begin{array}{l}(6, \\
605)\end{array}$ & & .61 & $\begin{array}{l}< \\
.001\end{array}$ \\
\hline $\begin{array}{l}\text { Identification with the Yellow } \\
\text { Vest. }\end{array}$ & $24.10 * * *$ & & & .67 & & $\begin{array}{l}< \\
.001\end{array}$ \\
\hline Political Ideology & $7.76^{* * *}$ & & & -.21 & & $\begin{array}{l}< \\
.001\end{array}$ \\
\hline Political orientation & $6.01 * * *$ & & & .16 & & $\begin{array}{l}< \\
.001\end{array}$ \\
\hline Income & 1.26 & & & -.03 & & .21 \\
\hline Age & .35 & & & .01 & & .73 \\
\hline Gender & $2.96 * *$ & & & .08 & & .003 \\
\hline Model 2 & & $223.74 * * *$ & $\begin{array}{l}(6, \\
605)\end{array}$ & & .69 & $\begin{array}{l}< \\
.001\end{array}$ \\
\hline $\begin{array}{l}\text { Identification with the Yellow } \\
\text { Vest. }\end{array}$ & $30.87 * * *$ & & & .77 & & $\begin{array}{l}< \\
.001\end{array}$ \\
\hline Political orientation & $3.44 * *$ & & & - & & .001 \\
\hline Political Extremism & $2.84 * *$ & & & .07 & & .005 \\
\hline Income & .48 & & & - & & .63 \\
\hline Age & $3.37 * *$ & & & .08 & & .001 \\
\hline Gender & 1.84 & & & .04 & & .067 \\
\hline
\end{tabular}

Note. ${ }^{*} p<.05, * * p<.01, * * * p<.001$. 
Table 2

Regression analyses testing the effect of identification with the Yellow Vest upon behavioural intentions to engage in collective action adjusted for age, gender, income, political orientation and political extremism (Study 1b, outcomes: Model $1=$ violent collective action, Model 2 = non-violent legal collective action, Model $3=$ non-violent illegal collective action $N=489)$

\begin{tabular}{|c|c|c|c|c|c|c|}
\hline Predictors & $t$ & $F$ & $d f$ & beta & $R^{2}$ & $P$ \\
\hline Model 1 & & $16.28 * * *$ & 6,475 & & .16 & $<.001$ \\
\hline Identification with the Yellow Vest. & $8.15^{* * *}$ & & & .36 & & $<.001$ \\
\hline Political orientation & $2.23 *$ & & & -.10 & & .027 \\
\hline Political Extremism & 1.86 & & & .08 & & .064 \\
\hline Income & .52 & & & .02 & & .61 \\
\hline Age & .17 & & & -.01 & & .87 \\
\hline Gender & 1.29 & & & .05 & & .20 \\
\hline Model 2 & & $89.40 * * *$ & 6,475 & & .52 & $<.001$ \\
\hline Identification with the Yellow Vest. & $20.92 * * *$ & & & .69 & & $<.001$ \\
\hline Political orientation & $2.57 *$ & & & -.09 & & .01 \\
\hline Political Extremism & $2.06^{*}$ & & & .07 & & .04 \\
\hline Income & 1.08 & & & .03 & & .28 \\
\hline Age & 1.29 & & & .04 & & .20 \\
\hline Gender & .06 & & & .01 & & .95 \\
\hline Model 3 & & $42.76 * * *$ & $(6,605)$ & & .34 & $<.001$ \\
\hline Identification with the Yellow Vest. & $13.56^{* * *}$ & & & .52 & & $<.001$ \\
\hline Political orientation & $2.75 * *$ & & & -.11 & & .006 \\
\hline Political Extremism & $2.40^{*}$ & & & .09 & & .017 \\
\hline Income & .97 & & & .04 & & .33 \\
\hline Age & $2.59 *$ & & & .10 & & .01 \\
\hline Gender & 1.00 & & & .04 & & .32 \\
\hline
\end{tabular}

Note.. ${ }^{*} p<.05, * * p<.01,{ }^{* * *} p<.001$. 
Table 3

Regression analyses testing the effect of identification with the Yellow Vest upon past collective action adjusted for age, gender, education, political orientation and social media use.

\begin{tabular}{llll}
\hline & Model 1 & Model 2 & Model 3 \\
\hline Education & $-.21^{* * *}$ & $-.19^{* * *}$ & $-.11^{*}$ \\
Age & -.01 & -.06 & .04 \\
Gender & $<-.01$ & -.01 & -.02 \\
Political orientation & .01 & .02 & .02 \\
Social media use & - & $.17^{* * *}$ & .02 \\
Yellow Vest & - & - & $.40^{* * *}$ \\
identification & & & \\
$F($ df $)$ & $5.84(4,509)$ & $7.44(5,508)$ & $20.45(6,507)$ \\
$R^{2}$ & .04 & .06 & .19 \\
\hline
\end{tabular}

